\title{
Mitogen-Activated Protein Kinase Kinase Kinase 4
}

National Cancer Institute

\section{Source}

National Cancer Institute. Mitogen-Activated Protein Kinase Kinase Kinase 4. NCI

Thesaurus. Code C147957.

Mitogen-activated protein kinase kinase kinase 4 (1608 aa, $\sim 182 \mathrm{kDa}$ ) is encoded by the human MAP3K4 gene. This protein plays a role in stress induced signaling pathways. 